Eur. J. Clin. Chem. Clin. Biochem.

Vol. 30, 1992, pp. $391-395$

(C) 1992 Walter de Gruyter \& Co.

Berlin $\cdot$ New York

\title{
A New Automated Method for Phenotyping Arylesterase (EC 3.1.1.2) Based Upon Inhibition of Enzymatic Hydrolysis of 4-Nitrophenyl Acetate by Phenyl Acetate
}

\author{
By L. Haagen and A. Brock \\ University of Aarhus, Department of Clinical Chemistry, Randers Centralsygehus, Randers, Denmark
}

(Received February 3/April 23, 1992)

Summary: A new method for phenotyping human serum arylesterase (EC 3.1.1.2) is described and evaluated. The aromatic esters, phenyl acetate and 4-nitrophenyl acetate, were compared as substrates for spectrophotometric measurement of arylesterase activity. A method for arylesterase phenotyping, based upon inhibition of the enzymatic hydrolysis of 4-nitrophenyl acetate by phenyl acetete, was developed. The method was applied to serum samples from 158 blood donors and showed a distinct separation of the three phenotypes defined by a reference method based on the ratio of paraoxonase activity to arylesterase activity using paraoxon and phenyl acetate as substrates. The method was adapted to a Cobas-Fara centrifugal analyser.

\section{Introduction}

Human serum possesses enzymatic activity capable of hydrolysing several aromatic carboxylic acid esters (e. g. phenyl acetate (1), $p$-nitrophenyl acetate (2), and 2-naphthyl acetate (1)) and organophosphate compounds (e. g. diethyl $p$-nitrophenyl phosphate (paraoxon) (3), chlorpyrifos oxon (4), and diisopropyl fluorophosphate (5)). A single enzyme species classified as arylesterase (A-esterase, paraoxonase, arylester hydrolase, EC 3.1.1.2) ${ }^{1}$ ) accounts for nearly all of these activities (5).

Arylesterase is a glycoprotein closely associated with the high density lipoprotein complex; $M_{\mathrm{r}}: 43000$; concentration: approximately $50 \mathrm{mg} / 1$ serum (5). According to a hypothesis of Eckerson et al. (3), the enzyme exists in two allozymic forms (isozyme A and isozyme B) which are controlled by two allels, ESA*A and $\mathrm{ESA}^{*} \mathrm{~B}$, at a single autosomal gene locus.

A number of chemical methods, based on quantitatively different kinetic properties of the two isozymes, have been developed to separate the two homozygous

\footnotetext{
1) Enzyme: Arylesterase, A-esterase, paraoxonase, arylester hydrolase (EC 3.1.1.2).
}

phenotypes $\mathrm{A}$ and $\mathrm{B}$, and the heterozygous phenotype $\mathrm{AB}(3,4,6,7)$. Using paraoxon as substrate, the two isozymes differ with respect to $\mathrm{NaCl}$-stimulation (6), $\mathrm{CaCl}_{2}$-stimulation $(6,7), \mathrm{pH}$ optimum $(8), K_{\mathrm{m}}$ value (9), and mean-activity level (8), and they differ in the ratio of paraoxonase activity to arylesterase activity (substrate: phenyl acetate) (3). The method described by Eckerson et al. (3), which we used as the reference method, is based on this ratio.

The present paper describes and evaluates a new method for phenotyping arylesterase in crude serum. The two substrates used are phenyl acetate and $p$ nitrophenyl acetate; these esters have been used as substrates in several studies for measuring arylesterase activity and are rather specific for this enzyme $(2,10$, $11,12)$. As shown in this study, there seems to be a trimodal relation between the enzymatic hydrolysis of the two substrates in a larger number of samples. This suggests that $p$-nitrophenyl acetate, like paraoxon, could be a "discriminating" substrate applicable for phenotyping arylesterase. In order to design a method without UV-photometry and adaptable for a CobasFara centrifugal analyser, we studied the inhibition of the enzymatic hydrolysis of $p$-nitrophenyl acetate 
by phenyl acetate and developed a method based on the inhibition characteristics. The phenotyping defined by the new method was compared with the phenotyping defined by the reference method.

\section{Materials and Methods}

Samples

Serum samples were obtained from blood donors in a Danish population. The samples were stored frozen at $-20^{\circ} \mathrm{C}$.

Arylesterase activity with phenyl acetate as sub strate

In this assay the arylesterase activity was measured as described by Eckerson et al. (3). The reaction mixture contained 1.0 $\mathrm{mmol} / \mathrm{l}$ phenyl acetate (Sigma P-2396) and $0.9 \mathrm{mmol} / 1 \mathrm{CaCl}_{2}$ in $9.0 \mathrm{mmol} / 1$ tris(hydroxymethyl)aminomethane $/ \mathrm{HCl}$ buffer $\mathrm{pH}$ 8.0. The reaction was initiated by adding a $20 \mu \mathrm{l}$ sample, prediluted with buffer $1+3$, to $3.0 \mathrm{ml}$ buffer/substrate reagent. The initial velocity of phenol formation during the hydrolysis of phenyl acetate was calculated from the increase of $A_{270 \mathrm{~nm}}$ recorded on a PM4 QII spectrophotometer (Zeiss, Germany); $\varepsilon_{270 \mathrm{~nm}}: 157 \mathrm{~m}^{2} / \mathrm{mol}$; reaction temperature: $25^{\circ} \mathrm{C}$. The progress curves were linear for at least $60 \mathrm{~s}$. Blanks were used to correct for non-enzymatic hydrolysis. All samples were run in duplicate.

Arylesterase activity with 4-nitrophenyl acetate as substrate

The reaction mixture contained $0.5 \mathrm{mmol} / 1$-nitrophenyl acetate (Sigma $\mathrm{N} 8130$ ) and $1.0 \mathrm{mmol} / \mathrm{l} \mathrm{CaCl}$ in $50 \mathrm{mmol} / \mathrm{l}$ Tris(hydroxymethyl)aminomethane/ $\mathrm{HCl}$ buffer $\mathrm{pH}$ 8.0. The reaction was initiated by adding $5 \mu \mathrm{l}$ sample, prediluted with buffer $1+6$, to the buffer/substrate reagent; final volume: 360 $\mu \mathrm{l}$. The velocity of $p$-nitrophenol formation during the hydrolysis of $p$-nitrophenyl acetate was recorded at $400 \mathrm{~nm}$ on a Cobas-Fara centrifugal analyser (Roche Ltd., Basel Switzerland) as a kinetic assay (20 to $50 \mathrm{~s}) ; \varepsilon_{400 \mathrm{~nm}}: 1640 \mathrm{~m}^{2} / \mathrm{mol}$; reaction temperature: $25^{\circ} \mathrm{C}$. Blanks were used to correct for non-enzymatic hydrolysis. All samples were run in duplicate.

\section{Paraoxonase activity}

Paraoxonase activity was measured by adapting the procedure described by Eckerson et al. (3) to a Cobas-Fara centrifugal analyser. The reaction mixture contained $1.0 \mathrm{mmol} / 1$ diethyl $p$ nitrophenyl phosphate (Sigma D 9286), $1.0 \mathrm{mmol} / \mathrm{l} \mathrm{CaCl}{ }_{2}$ and $1.0 \mathrm{~mol} / 1 \mathrm{NaCl}$ in $50 \mathrm{mmol} / \mathrm{l}$ glycine buffer $\mathrm{pH} 10.5$. The reaction was initiated by adding $20 \mu \mathrm{l}$ sample, prediluted with buffer $1+20$, to the buffer/substrate reagent; final volume: $380 \mu \mathrm{l}$. The initial velocity of $p$-nitrophenol formation was recorded at $400 \mathrm{~nm} ; \varepsilon_{400 \mathrm{~nm}}: 1810 \mathrm{~m}^{2} / \mathrm{mol}$; reaction temperature: $25^{\circ} \mathrm{C}$. The progress curves were linear for at least $120 \mathrm{~s}$. Blanks were used to correct for non-enzymatic hydrolysis. All samples were run in duplicate.

Inhibition of enzymatic hydrolysis of 4-nitrophenyl acetate by phenyl acetate

For determination of the non-inhibited arylesterase activity, the substrate concentration was $0.5 \mathrm{mmol} / \mathrm{l} p$-nitrophenyl acetate (Sigma N 8130); for determination fo the inhibited arylesterase activity, the substrate concentrations were $0.5 \mathrm{mmol} / 1$-nitrophenyl acetate and $1.0 \mathrm{mmol} / 1$ phenyl acetate (Sigma P-2396). In both cases the reaction mixture contained $1.0 \mathrm{mmol} / 1 \mathrm{CaCl}_{2}$ and $1.0 \mathrm{~mol} / 1 \mathrm{NaCl}$ in $25 \mathrm{mmol} / 1$ triethanolamine hydrochloride buffer $\mathrm{pH}$ 7.4. A stock solution of $p$-nitrophenyl acetate (1.27 $\mathrm{mmol} / \mathrm{l}$ ) was prepared in distilled water; the buffer including the salts, with or without phenyl acetate, was added just before use to minimize non-enzymatic hydrolysis. The reaction was initiated by adding $20 \mu \mathrm{l}$ sample, prediluted with buffer $1+20$, to the buffer/substrate reagent; final volume: $380 \mu$ l. The velocity of $p$-nitrophenol formation was recorded at $400 \mathrm{~nm}$ on a Cobas-Fara centrifugal analyser as a kinetic assay (40 to $95 \mathrm{~s}$ ); $\varepsilon_{400 \mathrm{~nm}}: 1400 \mathrm{~m}^{2} / \mathrm{mol}$; reaction temperature: $25^{\circ} \mathrm{C}$. Blanks were used to correct for non-enzymatic hydrolysis.

\section{Molar absorbances and statistics}

The molar absorbances of phenol and p-nitrophenol used in the calculations were determined on a PM4 QII spectrophotometer (Zeiss, Germany) at the specified $\mathrm{pH}$ values and wavelengths. Phenol stock standard (Sigma 960-25) and p-nitrophenol standard solution (Sigma 104-1) were used as standards.

All statistics were performed on an IBM PC/AT using the SPSS/ $\mathrm{PC}+$ software package (SPSS Inc., Chicago, IL).

\section{Results}

Enzymatic hydrolysis of 4-nitrophenyl acetate versus enzymatic hydrolysis of phenyl acetate

Figure 1 shows the arylesterase activities in 50 randomly selected sera using phenyl acetate and $p$-nitrophenyl acetate as substrates. No simple linear relation was observed. As indicated by the three lines in the figure, data are more probably described by three different linear relations.

Inhibition of enzymatic hydrolysis of 4-nitrophenyl acetate by phenyl acetate

Figure 2 shows the inhibited and non-inhibited arylesterase activities in 158 randomly selected sera, using $p$-nitrophenyl acetate as substrate and phenyl acetate as inhibitor. As indicated by the line in the figure, a cluster of points with a very high, linear correlation between inhibited (IA) and non-inhibited arylesterase (NIA) activity is clearly identified (IA $=0.428$ $\times \mathrm{NIA}+0.15 \mathrm{kU} / \mathrm{l} ; \mathrm{r}=9.996$ ). Figure 3 shows the distribution of the figure $\mathrm{X}=\left(\mathrm{IA}-\mathrm{IA}_{0}\right) / \mathrm{NIA}$ using $\mathrm{IA}_{0}=0.15 \mathrm{kU} / 1$ (ordinate intercept). The samples were segregated into three distinct groups with no overlap (G1: $\mathrm{X} \leq 0.24, \mathrm{~N}=15 ; \mathrm{G} 2: 0.24<\mathrm{X}$ $<0.37, \mathrm{~N}=72$; G3: $\mathrm{X}>0.37, \mathrm{~N}=71$ ).

Analytic inaccuracy of $\left(\mathrm{IA}-\mathrm{IA}_{0}\right) / \mathrm{NIA}$ was estimated from repeated analysis $(\mathrm{N}=56)$ of one sample from each of the three groups. To examine the influence of non-specific arylesterase activity from other carboxylic ester hydrolases $(10-12)$, an additional assay with preincubation of the samples in $1.0 \mu \mathrm{mol} / 1$ paraoxon for $60 \mathrm{~min}$ at $25^{\circ} \mathrm{C}$ was performed. Table 1 


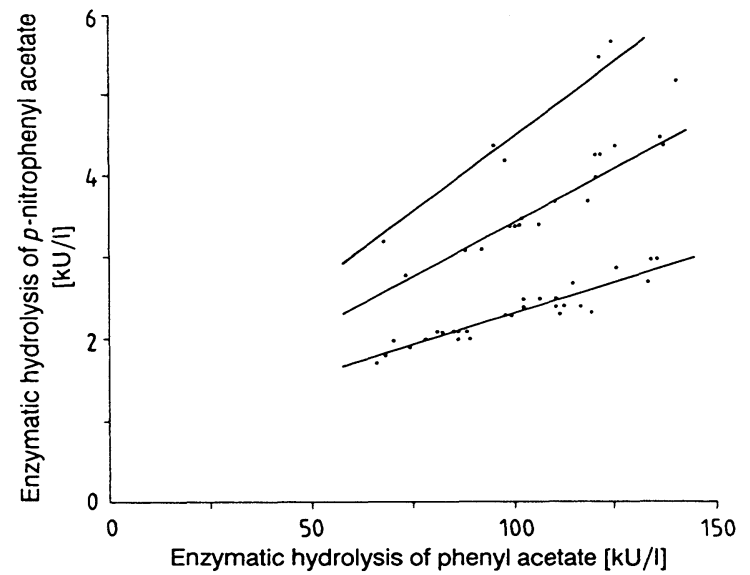

Fig. 1. Arylesterase catalytic activity concentrations in 50 randomly selected sera using phenyl acetate and p-nitrophenyl acetate as substrates. The three lines indicate the suggested trimodal pattern of distribution.

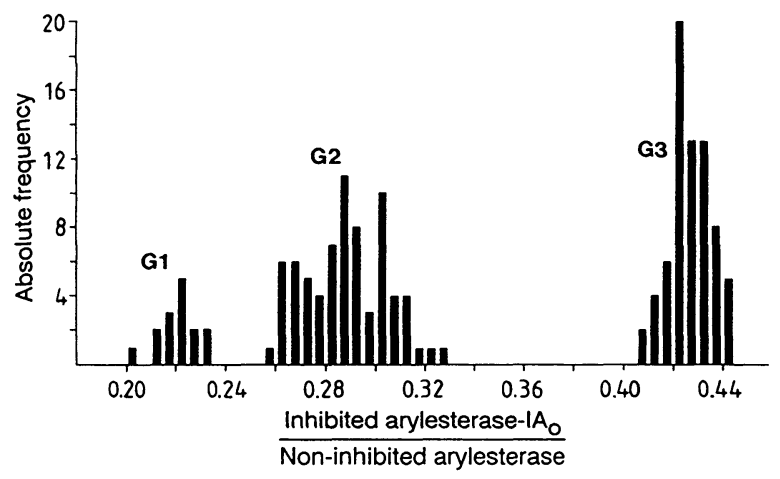

Fig. 3. Distribution of the quotient (inhibited arylesterase minus $\left(\mathrm{A}_{0}\right)$ /non-inhibited arylesterase within 158 randomly selected sera. $\mathrm{IA}_{0}$ : ordinate intercept of the line in figure 2. Three groups G1, G2, and G3 are clearly separated.

shows means and standard deviations (total, analytical and biological) of $\left(\mathrm{IA}-\mathrm{IA}_{0}\right) / \mathrm{NIA}$ within the groups G1, G2, and G3.

Ten samples from each group were phenotyped according to the method of Eckerson et al. (3). The phenotypes $(\mathrm{A}, \mathrm{AB}$, and $\mathrm{B})$ were determined by calculating the ratio $(p / a)$ of paraoxonase activity $(p)$ to arylesterase activity (a) using paraoxon and phenyl

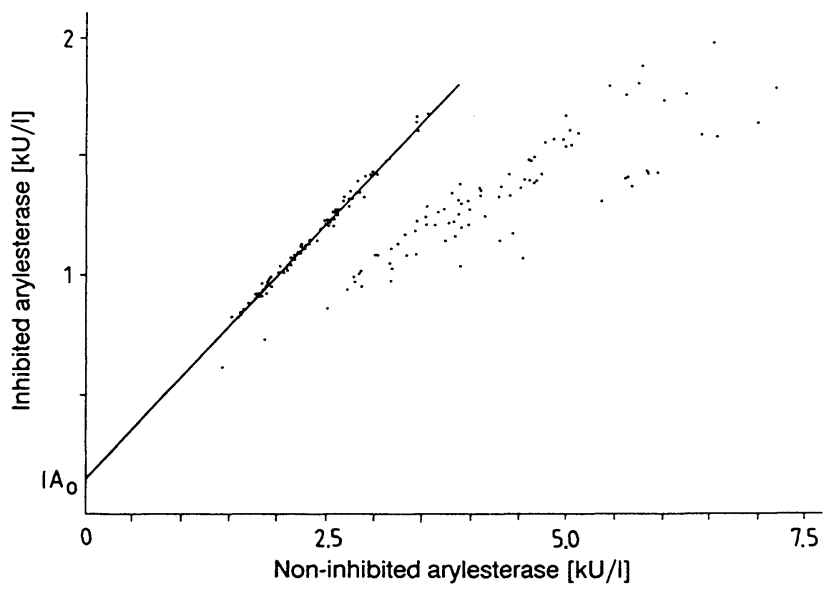

Fig. 2. Inhibition of enzymatic hydrolysis of p-nitrophenyl acetate by phenyl acetate in 158 randomly selected sera. A cluster of points is clearly identified as indicated by the line ( $\mathrm{IA}_{0}$ : ordinate intercept).
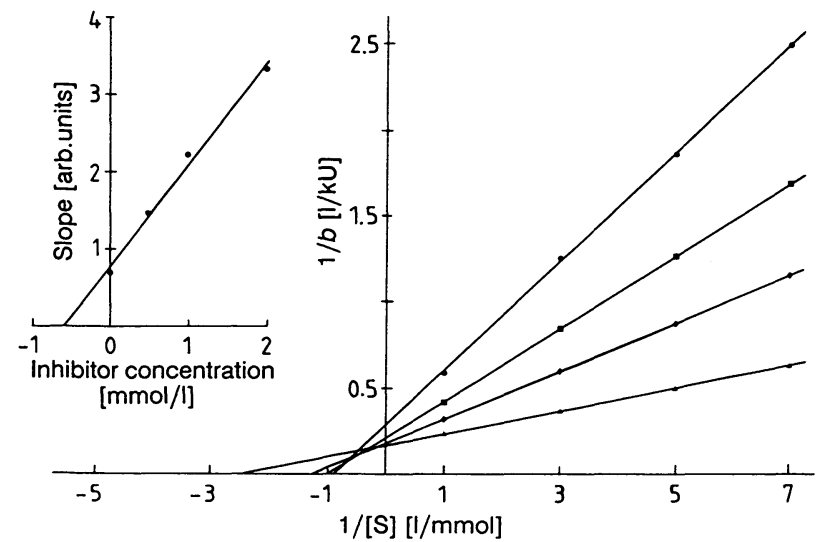

Fig. 4. Reaction kinetics of the arylesterase isozyme (G3). The catalytic activity concentrations $(b)$ of $p$-nitrophenyl acetate hydrolysis at the substrate concentrations ([S]) $1.00 \mathrm{mmol} / 1,0.33 \mathrm{mmol} / 1,0.20 \mathrm{mmol} / 1$, and $0.14 \mathrm{mmol} / 1$ were measured at various concentrations of phenyl acetate (inhibitor): $0.0 \mathrm{mmol} / \mathrm{l}(\boldsymbol{\Delta}), 0.5 \mathrm{mmol} / \mathrm{l}(\diamond), 1.0$ $\mathrm{mmol} / \mathrm{l}(\boldsymbol{\nabla})$, and $2.0 \mathrm{mmol} / \mathrm{l}(\bullet)$. Insert: slopes of the lines in the main figure as a function of inhibitor concentration.

acetate as substrates $\left(\mathrm{A}: \mathrm{p} / \mathrm{a}<5.5 \times 10^{-3}, \mathrm{AB}: 5.5\right.$ $\times 10^{-3} \leq \mathrm{p} / \mathrm{a} \leq 13.5 \times 10^{-3}$ and $\mathrm{B}: \mathrm{p} / \mathrm{a}>13.5$ $\times 10^{-3}$ ). All samples from $\mathrm{G} 3$ were of the phenotype $A$, and all samples from $\mathrm{G} 2$ were of the phenotype

Tab. 1. Means and standard deviations of $\left(\mathrm{IA}-\mathrm{IA}_{0}\right) / \mathrm{NIA}$ within the groups $\mathrm{G} 1, \mathrm{G} 2$, and G3.

\begin{tabular}{|c|c|c|c|c|c|c|c|c|c|}
\hline & \multicolumn{3}{|c|}{$\begin{array}{l}\text { Without preincubation } \\
\text { (paraoxon } 1 \mu \mathrm{mol} / \mathrm{l} \text { ) }\end{array}$} & \multicolumn{3}{|c|}{$\begin{array}{l}\text { After preincubation } \\
\text { (paraoxon } 1 \mu \mathrm{mol} / \mathrm{l})\end{array}$} & \multicolumn{3}{|c|}{$\begin{array}{l}\text { Repeated measurements } \\
\text { (one sample from each group) }\end{array}$} \\
\hline & G1 & G2 & G3 & G1 & G2 & G3 & G1 & G2 & G3 \\
\hline $\mathrm{N}$ & 15 & 72 & 71 & 14 & 72 & 70 & 55 & 56 & 55 \\
\hline Mean & 0.2206 & 0.2884 & 0.4269 & 0.2154 & 0.2841 & 0.4277 & 0.2213 & 0.3020 & 0.4392 \\
\hline $\mathrm{SD}_{\text {total }}$ & 0.0080 & 0.0163 & 0.0084 & 0.0078 & 0.0159 & 0.0099 & - & - & - \\
\hline $\mathrm{SD}_{\text {error }}$ & - & - & - & - & - & - & 0.0038 & 0.0039 & 0.0057 \\
\hline $\mathrm{SD}_{\text {biol. }}{ }^{*}$ & 0.0070 & 0.0158 & 0.0062 & - & - & - & - & - & $\cdot-$ \\
\hline
\end{tabular}

$*: \mathrm{SD}_{\text {biol. }}^{2}=\mathrm{SD}_{\text {total }}^{2}-\mathrm{SD}_{\text {error }}^{2}$ 
$\mathrm{AB}$; from $\mathrm{G} 1$, nine samples were of phenotype $\mathrm{B}$ and one sample was of phenotype $\mathrm{AB}\left(\mathrm{p} / \mathrm{a}=12.0 \times 10^{-3}\right.$; $\mathrm{X}=0.225$ )

Reaction kinetics of the arylesterase isozymes

The catalytic hydrolysis of $p$-nitrophenyl acetate at various concentrations of $p$-nitrophenyl acetate and phenyl acetate was measured using samples from $\mathrm{G} 1$ and G3 (two samples from each group were run in duplicate).

Figure 4 shows a double-reciprocal plot using a sample from G3. A similar plot was obtained using a sample from G1 (not shown). The reaction kinetics exclude simple competitive and uncompetitive inhibition, but is consistent with the model of non-competitive inhibition $\left(1 / \mathrm{v}=\left(K_{\mathrm{m}} / \mathrm{V}_{\max }\right)\left(1+\mathrm{i} / K_{\mathrm{i}}\right)(1 / \mathrm{s})\right.$ $\left.+\left(1 / \mathrm{V}_{\max }\right)\left(1+\mathrm{i} / K_{\mathrm{i}}\right)\right) . K_{\mathrm{m}}$ was estimated to be 0.31 $\mathrm{mmol} / \mathrm{l}(\mathrm{G} 1)$ and $0.40 \mathrm{mmol} / \mathrm{l}(\mathrm{G} 3) . K_{\mathrm{i}}$ was estimated to be $0.21 \mathrm{mmol} / \mathrm{l}(\mathrm{G} 1)$ and $0.60 \mathrm{mmol} / \mathrm{l}(\mathrm{G} 3)$ from inhibitor concentrations and slopes of the lines in the double-reciprocal plot (slope $\left.=\left(K_{\mathrm{m}} / \mathrm{V}_{\max }\right)\left(1+\mathrm{i} / K_{\mathrm{i}}\right)\right)$.

\section{Discussion}

The method described clearly divides the samples into three distinct groups, G1, G2, and G3. The segregation pattern observed is consistent with a two-allele model with co-dominant expression. According to this model the frequencies of the alleles in the sample population were estimated to be 0.323 and 0.677 . The observed distribution of the samples (G1: 15, G2: 72, and G3: 71) accords with the expected distribution (G1: 16.5, G2: 69.1, and G3: 72.4), assuming the population to be in Hardy-Weinberg equilibrium with respect to the two alleles $\left(\chi^{2}=0.284 ; 0.80<p\right.$ $<0.90)$. Comparing the new method of arylesterase phenotyping with the reference method, 29 of 30 samples were identically segregated into three subsets, and only 1 sample was assigned differently. It seems justified to consider that the phenotyping of the two methods is essentially the same, with the groups $\mathrm{G} 1$, $\mathrm{G} 2$, and $\mathrm{G} 3$ corresponding to the phenotypes $\mathrm{B}, \mathrm{AB}$, and A. According to Eckerson et al. (3) the frequency of the ESA*A allele is 0.685 and that of the ESA*B allele is 0.315 in a population of Caucasians. The allele frequencies found in the present study are quite close to these figures.
Preincubation of the samples in paraoxon did not change the grouping of any sample and, as shown in table 1, the total standard deviation of the figure $\left(\mathrm{IA}-\mathrm{IA}_{0}\right) / \mathrm{NIA}$ was not reduced. It is concluded that the results for non-specific arylesterase activity are negligibly affected by the presence of other carboxylic ester hydrolases, including cholinesterase, and that such affects cannot contribute to the biological standard deviation of the groups. Ortigoza-Ferado et al. (13) found that albumin has a paraoxonase activity which is not negligible at high $\mathrm{pH}$ values. This nonspecific activity presumably interferes with the paraoxonase activity measurements used in the reference method for phenotyping. Whether similar interference accounts for some of the biological standard deviation in the new method has not been examined.

The biological standard deviation of the intermediate group, G2, is more than twice the biological standard deviation of G1 and G3. This observation could possibly be explained by an inter-individual variation in the proportion of the activities of the two isozymes in heterozygous individuals.

Phenyl acetate and paraoxon are the two substrates used for arylesterase phenotyping in most methods published. Apparently the turnover number of the two isozymes differ with paraoxon, whereas they are identical with phenyl acetate $(3,14)$. In this study it is demonstrated that $p$-nitrophenyl acetate can be used instead of paraoxon as a substrate for differentiating the isozymes. The difference between the $\mathrm{K}_{\mathrm{i}}$ values of the isozymes $(0.60 \mathrm{mmol} / \mathrm{l}$ and $0.21 \mathrm{mmol} / \mathrm{l})$ is responsible for the segregation.

The assay conditions used were selected to optimize the separation of the three phenotype groups. The main problem is the low solubility, $0.6 \mathrm{~g} / 1$ water, and the relatively high spontaneous hydrolysis (11) of $p$ nitrophenyl acetate. The $\mathrm{pH}$ value 7.4 and the reaction temperature $25^{\circ} \mathrm{C}$ were selected to suppress the spontaneous hydrolysis. It was found that $1.0 \mathrm{~mol} / 1 \mathrm{NaCl}$ signficantly enhanced the separation of the groups; $\mathrm{CaCl}_{2}$ was added to secure adequate expression of enzyme activity $(15-17)$.

The method described is an easy and non-toxic method for large scale phenotyping and activity quantitation of arylesterase. The method is suitable for studies on the physiological functions of the enzyme and its relationship to pathological conditions (e.g. liver cirrhosis (18), familial hypercholesterolaemia, and insulin-dependent diabetes mellitus (19)). 


\section{References}

1. Augustinsson, K.-B. \& Ekedahl, G. (1962) On the Specificity of Arylesterases. Acta Chem. Scand. 16, 240-241.

2. Huggins, C. \& Lapides, J. (1947) Chromogenic substrates. IV. Acyl esters of p-nitrophenol as substrates for the colorimetric determination of esterase. J. Biol. Chem. 170, $467-482$.

3. Eckerson, H. W., Wyte, C. M. \& La Du, B. N. (1983) The Human Serum Paraoxonase/Arylesterase Polymorphism. Am. J. Hum. Genet. 35, 1126-1138.

4. Furlong, C. E., Richter, R. J., Seidel, S. L. \& Motulsky, A. G. (1988) Role of Genetic Polymorphism of Human Plasma Paraoxonase/Arylesterase in Hydrolysis of the Insecticide Metabolites Chlorpyrifos Oxon and Paraoxon. Am. J. Hum. Genet. 43, 230-238.

5. Gan, K. N., Smolen, A., Eckerson, H. W. \& La Du, B. N. (1991) Purification of human serum paraoxonase/arylesterase. Evidence for One Esterase Catalyzing Both Activities. Drug Metab. Dispos. 19, 100-106.

6. Eckerson, H. W., Romson, J., Wyte, C. \& La Du, B. N. (1983) The Human Serum Paraoxonase Polymorphism: Identification of Phenotypes by Their Response to Salts. Am. J. Hum. Genet. 35, 214-227.

7. Mueller, R. F., Hornung, S., Furlong, C. E., Anderson, J., Giblett, E. R. \& Motulsky, A. G. (1983) Plasma Paraoxonase Polymorphism: A New Enzyme Assay, Population, Family, Biochemical, and Linkage Studies. Am. J. Hum. Genet. 35, 393-408.

8. Eiberg, H. \& Mohr, J. (1981) Genetics of paraoxonase. Ann. Hum. Genet. 45, 323-330.

9. Flügel, M. \& Geldmacher-von Mallinckrodt, M. (1978) Zur Kinetik des Paraoxon-spaltenden Enzyms im menschlichen Serum (EC 3.1.1.2). Klin. Wochenschr. 56, 911 - 916.

10. Aldridge, W. N. (1953) Serum Esterases. 1. Two types of esterase (A and B) hydrolysing p-nitrophenyl acetate, propionate and butyrate, and a method for their determination. Biochem. J. 53, 110-117.
11. Koch, C.-D., Block, H. \& Molz, J. (1975) Zur Bestimmung der Arylesteraseaktivität im menschlichen Serum mit 4Nitrophenylazetat. Zeitschrift für Gastroenterologie 8, $695-703$.

12. Junge, W. \& Klees, H. (1984) Arylesterase. In: Methods of Enzymatic Analysis, vol. IV (Bergmeyer, H. U., Bergmeyer, J. \& Grassl, M., eds.) Verlag Chemie GmbH, Weinheim, pp. 8-14.

13. Ortigoza-Ferado, J., Richter, R. J., Hornung, S. K., Moltulsky, A. G. \& Furlong, C. E. (1984) Paraoxon Hydrolysis in Human Serum Mediated by a Genetically Variable Arylesterase and Albumin. Am. J. Hum. Genet. 36, 295-305.

14. La Du, B. N. (1988) Invited Editorial: The Human Serum Paraoxonase/Arylesterase Polymorphism. Am. J. Hum. Genet. 43, 227-229.

15. Erdös, E. G., Debay, C. R. \& Westermann, M. P. (1960) Arylesterase in blood: Effect of calcium and inhibitors. Biochem. Pharmacol. 5, 173-186.

16. Marton, A. V. \& Kalow, W. (1960) Inhibitors of aromatic esterase of human serum. Biochem. Pharmacol. 3, 149154.

17. Erdös, E. G., Debay, C. R. \& Westerman, M. P. (1959) Activation and inhibition of the arylesterase of human serum. Nature $184,430-431$.

18. Kawai, H., Yomoda, S. \& Inoue, Y. (1991) ELISA using monoclonal antibody to human serum arylesterase. Clinica Chimica Acta 202, 219-225.

19. Mackness, M. I., Harty, D., Bhatnagar, D., Winocour, P. H., Arrol, S., Ishola, M. \& Durrington, P. N. (1991) Serum paraoxonase activity in familial hypercholesterolaemia and insulin-dependent diabetes mellitus. Atherosclerosis 86, 193-199.

Axel Brock, $\mathrm{MD}, \mathrm{PhD}$

Department of Clinical Chemistry

Randers Centralsygehus

DK-8900 Randers 
